\title{
KNOWLEDGE MANAGEMENT, MARKET ORIENTATION AND COMPETITIVENESS OF SERVICE INDUSTRY COMPANIES
}

\begin{abstract}
The aim of this article is to examine the role of knowledge management and market orientation processes in creating competitive advantage by service industry companies. The publication is based on the results of a quantitative study in which 381 service industry companies were examined. The intensity of market orientation in enterprises was examined with a MKTOR scale developed by Narver and Slater ${ }^{2}$. The level of knowledge management processes was checked using KM Index scale which is based on numerous literature sources. The key finding of the study is that the creation of competitive advantage by service industry companies is strongly linked to the intensity of their knowledge management and market orientation processes. Nevertheless, more detailed analysis shows that the importance of these factors differs depending on the kind of services offered by such companies. The implementation of intensive activities in service industry companies in both areas - knowledge management and market orientation - brings the best results in terms of competitiveness of an enterprise. Nevertheless, increasing the intensity of operations even in one field may also improve the competitiveness level of a service company. Article brings unique insight into knowledge management and market orientation in various service industry companies and shows the link between these factors and competitiveness of analyzed firms.
\end{abstract}

Keywords: knowledge management, market orientation, service industry, competitive advantage, competitiveness.

\section{INTRODUCTION}

This article concentrates on examining the role of intensity of knowledge management and market orientation processes in creating competitive advantage by service industry companies. The choice of this problem has been motivated by a series of developments that can be observed in the current economy. One of the most visible and meaningful phenomena is the growing role of knowledge. Many famous philosophers tried to create a precise definition of this resource ${ }^{3}$ but even today there is no one established definition of knowledge.

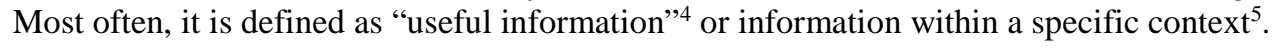

1 Dr Marcin Soniewicki, Department of International Marketing, Poznan University of Economics and Business, al. Niepodległości 10, 61-875 Poznań, Poland; e-mail: marcin.soniewicki@ue.poznan.pl, phone: +48 618543423 .

2 J.C. Narver, S.F. Slater, The Effect of a Market Orientation on Business Profitability, "Journal of Marketing” Vol. 54, No. 4, October, (1990), pp. 20-35.

3 Ch. Evans, Zarzadzanie wiedza, Warszawa 2005, s. 30.

4 A. Jashapara, Zarzadzanie wiedza, Warszawa 2006, s. 33.

5 P.N. Bukh, K.S. Christensen, J. Mouritsen, Knowledge Management and Intellectual Capital Establishing a Field of Practice, New York 2005, p. 24. 
Owing to the increasing importance of this resource our economy is now often called a knowledge-based economy. The term was coined by OECD in its report ${ }^{6}$. Gaczek notes that in the past knowledge used to be regarded as some sort of public resource ${ }^{7}$. For this reason, its function was probably not as noticeable as it is today, when its role in the economic processes has fundamentally changed ${ }^{8}$ and its importance in the economic growth, and in creating wealth of the entire economy, has greatly increased ${ }^{9}$. Many authors tried to comprehensively describe this phenomenon, but there is no single, broadly accepted definition of knowledge-based economy in the literature ${ }^{10}$. Brinkley attributes this difficulty to the fact that knowledge, which the concept is based on, is also very hard to define precisely ${ }^{11}$. In general, a knowledge-based economy is characterized by the use of its knowledge resource and by development of the industries based on this resource ${ }^{12}$.

The growing importance of knowledge has been particularly noticeable in companies. Knowledge is currently often considered as the key and most precious resource of contemporary enterprises ${ }^{13}$, which contributes more to creating value than capital or land ${ }^{14}$. Woodall, Lee and Stewart point out that current enterprises need a particular kind of competences, which are based mostly on effectiveness of their knowledge activities ${ }^{15}$.

In the literature one can find many concepts that are supposed to help and organize activities of companies in the area of knowledge and learning, such as knowledge management, learning organization or organizational learning. However, the first of them is by far the most popular ${ }^{16}$. Handzic and Zhou claim that knowledge management is perceived as companies' response to changes taking place in the global economy ${ }^{17}$. There are many definitions of knowledge management available in the literature ${ }^{18}$. Among the most interesting ones is the definition developed by Paliszkiewicz ${ }^{19}$, who defines knowledge management

6 OECD, The Knowledge-Based Economy, Paris 1996, p. 1.

7 W.M. Gaczek, Gospodarka oparta na wiedzy w regionach europejskich, Warszawa 2009, s. 21.

8 P. Nijkamp, I. Siedschlag, Innovation, Growth and Competitiveness. Dynamic Regions in the Knowledge-Based World Economy, Springer, Berlin 2011, p. 15.

9 B. Kahin, D. Foray, Advancing Knowledge and the Knowledge Economy, Cambridge 2006, p. 17.

${ }^{10}$ Ch. Karlsson, B. Johansson, R.R. Sough, Entrepreneurship and Dynamics in the Knowledge Economy, New York 2006, p. 12.

11 I. Brinkley, Defining the knowledge economy, London 2006, p. 29.

${ }^{12}$ M. Moszkowicz, P. Kubiński, Edukacja akademicka a tworzenie w Polsce gospodarki opartej na wiedzy [w:] Wiedza w gospodarce i gospodarka oparta na wiedzy. Edukacja w gospodarce opartej na wiedzy, M. Hopej, M. Moszkowicz, J. Skalik, Wrocław 2010, s. 133-134; W. Welfe, Gospodarka oparta na wiedzy, Warszawa 2007, s. 7.

13 J.J. Brdulak, Zarzadzanie wiedza a proces innowacji produktu, Warszawa 2005, s. 17; J. Liebowitz, Making Cents Out of Knowledge Management, Laham 2008, p. 1.

14 Z. Szyjewski, J.S. Nowak, J.K. Grabara, Strategie Informatyzacji i Zarzadzania Wiedza, Warszawa 2004, s. 386.

$15 \mathrm{~J}$. Woodall, M. Lee, J. Stewart, The knowledge revolution and the knowledge economy: the challenge for HRD. New Frontiers in HRD, London 2004, p. 165.

16 A. Jashapara, Zarzadzanie..., s. 307.

17 M. Handzic, A.Z. Zhou, Knowledge Management. An Integrative Approach, Oxford 2005, p. 3.

18 P.K. Ahmed, K.K. Lim, A.Y.E. Loh, Learning Through Knowledge Management, Oxford 2002, p. 12; M.J. Stankiewicz, Zarządzanie Wiedzq Jako Kluczowy Czynnik Międzynarodowej Konkurencyjności Przedsiębiorstwa, Torun 2006, s. 118.

19 J.O. Paliszkiewicz, Zarzadzanie wiedza w matych i średnich przedsiębiorstwach - koncepcja oceny i modele, Warszawa 2007. 
as ,,a systematic, organized process of locating, acquiring, transferring, using and saving knowledge, which is based on particular technologies and cultural environment, whose goal is to increase of the company's results" ${ }^{20}$. The importance of knowledge management is reflected in the opinion of Bali, Wickramasinghe and Lahaney, who argue that it is one of the key concepts of our times ${ }^{21}$.

The paper is a research article based on quantitative study. It consists of six parts. After introduction, theoretical background and research methods used in the analyses have been presented. Subsequently, comes the key section of the article which shows the results of the empirical research. At the end, conclusions as well as limitations and recommendations for future research have been delivered.

\section{THEORETICAL BACKGROUND}

Creation of competitive advantage by any enterprise is a very complex issue. Are intensive knowledge management processes sufficient to achieve this goal? One needs to remember that knowledge management is only a tool which may, or may not, be used properly and for the right purpose. The crucial element is the character of business processes and strategies that a company has in place. Even the best implementation of a tool such as knowledge management is not going to increase a company's competitiveness.

Managers of contemporary companies often forget that they do not exist only in a knowledge-based economy, but they also exist in a market economy. For companies operating in the market economy, current knowledge of the market is crucial, because they are not research institutions and need to concentrate on useful knowledge. But what does 'useful' mean? The criterion of usefulness is the market which the company serves. Each market is the state of constant change. Contemporary companies cannot collect and use knowledge effectively without first getting to know the usefulness criterion, which is the market. Moreover, this task is much more difficult now than it was in the past owing to a much faster pace of market changes. That is why contemporary companies need high market orientation $^{22}$.

Market orientation, according to Shapiro, consists of three elements: understanding how customers use products offered by a company, the use of market knowledge by all departments of the company and analysis of its competitors' operations ${ }^{23}$. It must be emphasized that high market knowledge is only the first step to achieving competitive advantage. Companies need proper knowledge management to operate effectively in the knowledge-based economy and use their acquired market knowledge well in their own business processes.

\footnotetext{
${ }^{20}$ Ibidem, p. 38.

${ }^{21}$ R.K. Bali, N. Wickramasinghe, B. Lahaney, Knowledge Management Primer, London 2009, p. 1.

${ }_{22}$ M. Soniewicki, The company's international competitive advantage - the role of knowledge, Warsaw 2015.

${ }^{23}$ B.P. Shapiro, What the Hell is 'Market Oriented'?, "Harvard Business Review” Vol. 66 (1988), pp. 119-125.
} 
This article continues investigations undertaken in previous studies ${ }^{24}$. The importance of both knowledge management and market orientation processes for competitiveness of companies in internationalization processes had been empirically confirmed previously ${ }^{25}$. In the other study, the importance of cooperative knowledge sources for competitiveness of service industry companies was examined ${ }^{26}$, while the third study explored the characteristics of knowledge management processes in the same kind of enterprises ${ }^{27}$.

Service industry companies are an interesting subject of research because they constitute a crucial element of postindustrial economy ${ }^{28}$. This category of enterprises also generates a substantial share of developed countries' GDP ${ }^{29}$.

This article presents the results of a study aimed at investigating the importance of intensive knowledge management and market orientation processes for competitiveness of service industry enterprises. This area is worth analyzing as it has not been examined in detail the context of service industry companies. Moreover, previous studies have shown that service industry companies, which use more cooperative knowledge sources, are also more competitive than their closest competitors ${ }^{30}$. Furthermore, knowledge management processes are more intensive among this kind of companies in comparison to manufacturing and trade industry enterprises ${ }^{31}$. Consequently, this article tries to answer three research questions:

- Are service industry companies with highly intensive market orientation and knowledge management processes more competitive than service industry companies without either one or both of these qualities?

- What are the intensities of market orientation and knowledge management processes in various types of service industry companies and in companies with different levels of employment?

- Is the competitiveness of service industry companies of various types and with different employment levels improved by the existence of highly intensive market orientation and knowledge management processes in the company?

\footnotetext{
${ }^{24}$ M. Soniewicki, Wykorzystanie kooperacyjnych źródet wiedzy w przedsiębiorstwach ustugowych, "Studia Oeconomica Posnaniensia" No. 1 (2014a), s. 46-60; M. Soniewicki, The characteristics of knowledge management processes in the Polish service industry companies, "Przegląd Organizacji” No. 7 (2014b), pp. 40-46; M. Soniewicki, The company's....

Despite the fact, that analyses in this one and cited article are based on the same data set, collected in one empirical research, they are not entirely comparable. This is because in the analyses for this article not all examined service industry entities have been included due to missing data - scope of this article is wider. Moreover, when calculating KM Index in this article more knowledge sources, in comparison to the other article, have been included..

${ }^{25}$ M. Soniewicki, The company's...

${ }^{26}$ M. Soniewicki, Wykorzystanie kooperacyjnych..., s. 46-60.

${ }^{27}$ M. Soniewicki, The characteristics..., pp. 40-46.

${ }^{28}$ S. Grönfeldt, J. Stroher, Service Leadership. The Quest for Competitive Advantage, SAGE Publications, London 2006, p. 24.

${ }_{29}$ M.A. Weresa, Establishing Competitive Advantages in the Service Sector in EU Member States, Peter Lang, Frankfurt am Main 2010, p. 7.

${ }^{30}$ M. Soniewicki, Wykorzystanie kooperacyjnych..., s. 46-60.

${ }^{31}$ M. Soniewicki, The characteristics..., p. 42.
} 


\section{RESEARCH METHODS}

The analyses presented in the article are based on the data gathered in a study financed by the National Science Center's grant Preludium $2^{32}$. The study was conducted in 2012 and at the beginning of 2013. The sample was drawn from the Kompass Poland database which contains information about all sorts of firms operating in Poland. Respondents were managers and employees of companies in the sample. There were two forms of research questionnaire developed. The first one was an online questionnaire prepared by the author with technical assistance from a computer scientist. The other was a traditional, paper-based questionnaire, as not all of the companies included in the Kompass Poland database agreed to be contacted electronically. The results of both questionnaires were analyzed jointly. Overall, almost 1300 fully filled questionnaires were returned. 381 of them were obtained from various service enterprises. A detailed description of the sample of enterprises is presented in Tables 1 and 2.

Table 1. The number of service companies of particular size in the examined sample

\begin{tabular}{|c|c|}
\hline No. of employees & $\begin{array}{c}\text { No. of } \\
\text { enterprises }\end{array}$ \\
\hline Less than 10 & 98 \\
\hline $10-49$ & 166 \\
\hline $50-249$ & 91 \\
\hline 250 or more & 26 \\
\hline & Total: \\
\hline
\end{tabular}

Source: own study.

Table 2. The number of service companies of particular type in the examined sample

\begin{tabular}{|c|c|}
\hline Type of service companies & $\begin{array}{c}\text { No. of } \\
\text { enterprises }\end{array}$ \\
\hline Information and communication services & 63 \\
\hline Hotel and restaurant services & 24 \\
\hline Real estate services & 17 \\
\hline Transport services & 28 \\
\hline Scientific, technical and other professional services & 112 \\
\hline Financial and insurance services & 17 \\
\hline Other services & 120 \\
\hline Total: & $\mathbf{3 8 1}$ \\
\hline
\end{tabular}

Source: own study.

Table 1 presents analyzed sample divided into groups according to the level of their employment. In the questionnaire, respondents were asked about the real level of employment in their enterprises, including contract workers, as this hiring method is currently commonly used in Poland.

As we can read from table 1, most of examined service companies employ 10 to 49 workers. Not many large companies, employing 250 or more workers, have been analyzed,

32 The research has been part of the project financed by Polish National Science Center, Preludium 2 grant, awarded under the decision no. DEC-2011/03/N/HS4/00429. 
but that is probably because such big service companies are not numerous in Poland. The following table brings more detailed division of analyzed companies.

Table 2 divides analyzed sample into particular types of service companies. The categories used were taken from the Polish Business Classification ${ }^{33}$. It is quite important division as, for example, hotel and restaurant services considerably differ from financial and insurance services and it is vital to analyze them separately.

The important idea in creating the research questionnaire was to make it relatively simple, short and understandable for respondents. The questionnaire went through many pretests and pilot studies in order to improve it, make it easy to fill out and receive as many replies from companies as possible. All the questions included had been based on appropriate literature.

As far as market orientation is concerned, the literature provides two popular scales that can be used in order to measure its intensity in enterprises. The first one - MKTOR, was developed by Narver and Slater ${ }^{34}$. The second one - MARKOR, was developed by Kohli, Jaworski and Kumar ${ }^{35}$. According to Kaur, Sharma and Seli both are still popular and are used by researchers in their original versions ${ }^{36}$.

For purposes of the empirical study described in this article, the former scale, developed by Narver and Slater was used ${ }^{37}$. Positive opinions about it, found in the literature, are the first reason for this choice. Pelham and Wilson claim that the statistical reliability of MKTOR is higher in comparison to MARKOR ${ }^{38}$. The other reason is the fact that MKTOR has already been successfully used in a study conducted in Poland by Hooley et al. ${ }^{39}$.

MKTOR consists of fourteen questions divided into three parts. The first one consists of six questions concerning customer orientation. The second part consists of four questions which refer to competitor orientation. The last section, the remaining four questions, concerns the company's interfunctional coordination ${ }^{40}$.

Knowledge management intensity was examined by a measure developed by the author of this article - the KM Index. The measure consists of a series of questions, each based on the knowledge management literature ${ }^{41}$. The KM Index was designed in the absence of one widely accepted measure of knowledge management intensity in the enterprises. This is the case, as Kłak explains, because knowledge management is a relatively young field ${ }^{42}$. The

${ }^{33}$ GUS, PKD 2007, 2007, http://www.stat.gov.pl/klasyfikacje/pkd_07/pdf/2_PKD-2007-schemat_2.pdf (26.03.2012 r.).

${ }^{34}$ J.C. Narver, S.F. Slater, The Effect of a Market..., pp. 20-35.

35 A.K. Kohli, B.J. Jaworski, A. Kumar, MARKOR: A Measure of Market Orientation, "Journal of Marketing Research" Vol. 30, November (1993), pp. 467-477.

${ }^{36}$ G. Kaur, R.D. Sharma, N. Seli, A Balanced Approach towards Market Orientation, "Vikalpa", Vol. 38, No. 3, July-September (2013), p. 52.

37 J.C. Narver, S.F. Slater, The Effect of a Market..., pp. 20-35.

38 A.M. Pelham, D.T. Wilson, A Longitudinal Study of the Impact of Market Structure, Firm Structure, Strategy, and Market Orientation Culture on Dimensions of Small-Firm Performance, "Journal of the Academy of Marketing Science" Vol. 24, No. 1 (1996), p. 33.

${ }^{39}$ G. Hooley et. al., Market Orientation in the Transition Economies of Central Europe, "Journal of Business Research" 50 (2000), pp. 273-285.

40 Ibidem, p. 277.

${ }^{41}$ M. Soniewicki, The company's...

42 M. Kłak, Zarządzanie wiedza we wspótczesnym przedsiębiorstwie, Kielce 2010, s. 49. 
KM Index consists of four parts: knowledge acquisition, the use of knowledge management information technologies, knowledge distribution and knowledge implementation.

The competitiveness level of companies in the sample was measured by means of the Competitiveness Index. This method was developed by Fonfara and has been successfully applied and tested in many studies ${ }^{43}$. It is based on financial and non-financial aspects of the company's performance compared with its closest competitors.

A 5-point Likert scale was used in the KM Index, MKTOR and Competitiveness Index, in which number 5 always means very high and number 1 indicates very low. 3 represents a neutral answer. One unified scale was used as a research tool in order to make the questionnaire simpler and easier to understand for respondents. The simplicity of the questionnaire also improved the response rate and the quality of answers. The reliability of the scales was tested by Cronbach's Alpha statistic and its value for each scale was above 0.7.

The aim of the article is to check whether service industry companies with highly intensive knowledge management processes (KM) and high market orientation (MO) are more competitive. That is why in the case of KM and MO intensity, the sampled companies were divided into two groups: those above and below average. The presence of the two variables (KM and MO) resulted in four groups. Nevertheless, the most interesting group includes companies where the intensity of both KM and MO was above the average. That is why in some places only two groups are used - companies with KM and MO above the average and the rest. The value of 3 was chosen as the cutting point as it is the central, neutral value in the 5-point Likert scale.

The existence of statistically significant differences in values of the Competitiveness Index within each group of enterprises was determined by Student's t-test. The calculations were conducted using the $\mathrm{R}$ programming language with RStudio.

\section{RESEARCH RESULTS}

The first analysis, presented in Table 3, shows the competitiveness level of the sampled service companies, which are divided into groups depending on their intensity of knowledge management (KM) and market orientation (MO). Two levels of intensity of KM and MO are distinguished - high, which means $>=3$ and low $<3$. As we can read from the table, the majority $(68.4 \%)$ of the companies is characterized by a high level of KM and MO. The Competitiveness Index for these businesses is also the highest - 3.26. The level above three means that they are, on average, more competitive than their closest competitors. Furthermore, the remaining companies have much lower values of the Competitiveness Index. It means that a lower than average intensity of even one of the factors - either KM or MO may be linked to a substantial likelihood of a company becoming less competitive than their closest competitors. Moreover, there are considerable differences between the range of the Competitiveness Index for companies intensively engaged in both KM and MO and the other groups. They are statistically significant in most cases. The difference is not statistically significant in case of companies with high KM and low MO, but probably because of

${ }^{43} \mathrm{~K}$. Fonfara, Zachowanie przedsiębiorstwa $w$ procesie internacjonalizacji - podejście sieciowe, Warszawa 2009; K. Fonfara, The Development of Business Networks in the Company Internationalisation Process, Poznań 2012; M. Ratajczak-Mrozek, Sieci biznesowe a przewaga konkurencyjna przedsiębiorstw zaawansowanych technologii na rynkach zagranicznych, Poznań 2010; M. Soniewicki, The company's... 
the low number of such companies (only 11) in the sample. It must be emphasized that the service companies with a low level of intensity of both KM and MO were also characterized by a very low value of the Competitiveness Index -2.52 .

Table 3. Competitiveness of service companies depending on their knowledge management and market orientation intensity ${ }^{44}$

\begin{tabular}{|c|c|c|c|}
\hline $\begin{array}{c}\text { No. of } \\
\text { enterprises }\end{array}$ & $\begin{array}{c}\text { Knowledge } \\
\text { management (KM) } \\
\text { and market orientation (MO) } \\
\text { intensity }\end{array}$ & $\begin{array}{c}\text { Competitiveness } \\
\text { Index }\end{array}$ & $\begin{array}{c}\text { Competitiveness } \\
\text { Index } \\
\text { difference }\end{array}$ \\
\hline 261 & High KM and high MO & 3.26 & - \\
\hline 11 & High KM and low MO & 2.95 & 0.31 \\
\hline 72 & Low KM and high MO & 2.84 & $\mathbf{0 . 4 2} * * *$ \\
\hline 37 & Low KM and low MO & 2.52 & $\mathbf{0 . 7 4 * * *}$ \\
\hline
\end{tabular}

Source: own study.

The above results do not account for different types of service companies. For this purpose the companies in the sample were further divided into groups depending on the level of employment and type of services offered.

Table 4 shows the intensity of knowledge management and market orientation processes in service companies of various sizes. It also presents differences between companies with the highest level of KM or MO and the others, including their statistical significance. The first thing that can be noticed is the fact that the differences in KM are larger than in the case of MO. Another observation is that larger enterprises are characterized by more intensive $\mathrm{KM}$ and $\mathrm{MO}$ processes. However, this pattern is not observed for large enterprises employing 250 or more workers. This might be caused by a relatively small number of such companies in the sample - only 26 (see table 1).

Table 4. Knowledge management and market orientation intensity in service companies of particular size

\begin{tabular}{|c|c|c|c|c|}
\hline No. of employees & $\begin{array}{c}\text { Knowledge } \\
\text { management } \\
\text { intensity }\end{array}$ & Difference & $\begin{array}{c}\text { Market } \\
\text { orientation } \\
\text { intensity }\end{array}$ & Difference \\
\hline Less than 10 & 3.19 & $\mathbf{- 0 . 2 0} * *$ & 3.60 & -0.07 \\
\hline $10-49$ & 3.27 & $\mathbf{- 0 . 1 3}$ & 3.63 & -0.05 \\
\hline $50-249$ & 3.39 & - & 3.67 & - \\
\hline 250 or more & 3.25 & -0.14 & 3.54 & -0.14 \\
\hline
\end{tabular}

Source: own study.

The existence of more intensive KM processes in larger enterprises can be attributed to the fact that knowledge in smaller enterprises can flow relatively effectively without sophisticated, extensive knowledge management processes. The relatively low level of KM and MO level in large enterprises (250 employees or more) may be linked to the fact that the study was conducted in Poland, where many large companies are state owned and are not considered effective and market oriented.

$44 * \mathrm{p}<0.1, * * \mathrm{p}<0.05, * * * \mathrm{p}<0.01$ 
Another conclusion that can be drawn from analyzing Table 4 is the fact that average levels of intensity of knowledge management and market orientation processes are above 3 regardless of company size. This may result from the fact that for this kind of enterprises knowledge is the key resource used in creating their value added. Often companies of this kind have close contact with customers, a factor which also facilitates processes of market orientation.

The division of service companies in terms of level of employment shows specific aspects of KM and MO processes in these companies. Nevertheless, another criterion - type of services provided - seems to be more important and interesting. Table 5 shows the intensity of KM and MO in service companies of various types.

Table 5. Knowledge management and market orientation intensity in service firms of particular type

\begin{tabular}{|c|c|c|c|c|}
\hline Type of service companies & $\begin{array}{c}\text { Knowledge } \\
\text { management } \\
\text { intensity }\end{array}$ & Difference & $\begin{array}{c}\text { Market ori- } \\
\text { entation } \\
\text { intensity }\end{array}$ & Difference \\
\hline $\begin{array}{c}\text { Information and communication } \\
\text { services }\end{array}$ & 3.46 & 0.00 & 3.73 & -0.20 \\
\hline Hotel and restaurant services & 3.00 & $\mathbf{- 0 . 4 6 * * *}$ & 3.41 & $\mathbf{- 0 . 5 2} * * *$ \\
\hline Real estate services & 2.97 & $\mathbf{- 0 . 4 9 * * *}$ & 3.41 & $\mathbf{- 0 . 5 2 * *}$ \\
\hline Transport services & 3.46 & - & 3.93 & - \\
\hline $\begin{array}{c}\text { Scientific, technical and other } \\
\text { professional services }\end{array}$ & 3.31 & -0.15 & 3.64 & $\mathbf{- 0 . 2 9} * *$ \\
\hline Financial and insurance services & 3.34 & -0.12 & 3.72 & -0.21 \\
\hline Other services & 3.20 & $\mathbf{- 0 . 2 5} * *$ & 3.55 & $\mathbf{- 0 . 3 8 * * *}$ \\
\hline
\end{tabular}

Source: own study.

As we can see, particular types of service companies differ considerably in terms of intensity of their knowledge management and market orientation processes. Most of these differences are statistically significant. In this case there are much greater average differences in intensity of KM and MO between the groups than in the case of employment level. The highest level of knowledge management intensity can be observed in enterprises offering information and communication technology services as well as transport services. As far as market orientation is concerned, the most intensive processes can be observed among firms providing transport services. Nevertheless, intensive activities in this area are also undertaken by companies offering information and communication technology services as well as financial and insurance services. Analyzed from the point of view of employment level, the intensity of the two kinds of processes was above 3, regardless of the company size. In the case of the type of service, there is one exception - real estate services. The last interesting finding is that in both divisions MO processes are always more intensive than KM processes.

The two tables above deliver information on the intensity of KM and MO processes in various types of service industry companies. However, the most interesting question is how the levels of Competitiveness Index vary in particular types of service enterprises depending 
on the intensity of KM and MO. Such comparisons have been presented in the two following tables (6 and 7). In the mentioned tables high intensity is defined as high intensity of both kinds of processes: $\mathrm{KM}$ and $\mathrm{MO}(\geq 3)$. Low means that intensity of at least one of them $-\mathrm{MO}$ or $\mathrm{KM}-$ is below $3(<3)$.

The first and most important conclusion that we can read from the table 6 is that companies of all sizes with high intensity of both KM and MO processes are on average more competitive than other businesses. Moreover, the differences in Competitiveness Index are in all cases statistically significant.

Table 6. The difference in Competitiveness Index values among service companies of particular size with high and low level of intensity of knowledge management and market orientation

\begin{tabular}{|c|c|c|c|}
\hline Employment & $\begin{array}{c}\text { Knowledge management } \\
\text { and market orientation } \\
\text { intensity }\end{array}$ & $\begin{array}{c}\text { Competitiveness } \\
\text { Index }\end{array}$ & $\begin{array}{c}\text { No. of } \\
\text { enterprises }\end{array}$ \\
\hline \multirow{3}{*}{ Less than 10} & High (both) & 2.97 & 61 \\
\hline & Low (either one or both) & 2.57 & 37 \\
\hline & $\begin{array}{r}\text { Difference } \\
\end{array}$ & $0.40 * * *$ & \\
\hline \multirow{3}{*}{$10-49$} & High (both) & 3.27 & 108 \\
\hline & Low (either one or both) & 2.78 & 58 \\
\hline & $\begin{array}{rr}\text { Difference } \\
\end{array}$ & $0.49 * * *$ & \\
\hline \multirow{3}{*}{$50-249$} & High (both) & 3.38 & $7 \overline{75}$ \\
\hline & Low (either one or both) & 3.05 & 16 \\
\hline & $\begin{array}{r}\text { Difference } \\
\end{array}$ & $0.33 * *$ & \\
\hline \multirow{3}{*}{250 or more } & High (both) & 3.76 & 17 \\
\hline & Low (either one or both) & 2.81 & 9 \\
\hline & Difference & $0.96 * * *$ & \\
\hline
\end{tabular}

Source: own study.

In case of the small (10-49 employees) and smallest (less than 10 employees) enterprises the results are most reliable. There are many businesses in these groups characterized by low and high intensity of examined processes. The differences in competitiveness are also quite large -0.40 and 0.49 .

The results in two other groups are less trustworthy, although still statistically significant. In the case of medium size businesses (50-249 employees) there are not so many companies in the group characterized by low intensity of examined processes. It may be the cause of smaller Competitiveness Index value's difference. On the other hand, in the case of large enterprises (250 employees or more) the difference of Competitiveness Index value is very big but the number of enterprises of such size in the sample is quite low, only 26.

In general, apart from one group, the larger the service companies are, the bigger average Competitiveness Index differences can be observed in the presented analysis. This is probably because it is easier for smaller businesses to effectively manage their knowledge without sophisticated KM processes.

The following table (7) presents the comparison of Competitiveness Index values between firms with high and low intensity of analyzed processes. It has been created in the same way as the one in the previous table (6). This time, studied companies have been grouped according to the type of services they offer. 
Table 7. The difference in Competitiveness Index values among service companies of particular type with high and low level of intensity of knowledge management and market orientation

\begin{tabular}{|c|c|c|c|}
\hline Type of companies & $\begin{array}{c}\text { Knowledge management } \\
\text { and market orientation } \\
\text { intensity }\end{array}$ & $\begin{array}{l}\text { Competitiveness } \\
\text { Index }\end{array}$ & $\begin{array}{l}\text { No. of } \\
\text { enterprises }\end{array}$ \\
\hline \multirow{3}{*}{$\begin{array}{l}\text { Information and com- } \\
\text { munication services }\end{array}$} & High (both) & 3.22 & 53 \\
\hline & Low (either one or both) & 2.68 & 10 \\
\hline & Difference & $0.54 * *$ & \\
\hline \multirow{3}{*}{$\begin{array}{l}\text { Hotel and restaurant } \\
\text { services }\end{array}$} & High (both) & 2.95 & 11 \\
\hline & Low (either one or both) & 2.48 & 13 \\
\hline & Difference & 0.47 & \\
\hline \multirow{3}{*}{ Real estate services } & High (both) & 3.92 & 9 \\
\hline & Low (either one or both) & 2.81 & 8 \\
\hline & Difference & $1.10 * *$ & \\
\hline \multirow{3}{*}{ Transport services } & High (both) & 3.46 & 23 \\
\hline & Low (either one or both) & 3.05 & 5 \\
\hline & Difference & 0.41 & \\
\hline \multirow{3}{*}{$\begin{array}{l}\text { Scientific, technical } \\
\text { and other professional } \\
\text { services }\end{array}$} & High (both) & 3.25 & 76 \\
\hline & Low (either one or both) & 2.83 & 36 \\
\hline & Difference & $0.43 * * *$ & \\
\hline \multirow{3}{*}{$\begin{array}{c}\text { Financial and insurance } \\
\text { services }\end{array}$} & High (both) & 3.25 & 12 \\
\hline & Low (either one or both) & 3.15 & 5 \\
\hline & Difference & 0.10 & \\
\hline \multirow{3}{*}{ Other services } & High (both) & 3.22 & 77 \\
\hline & Low (either one or both) & 2.70 & 43 \\
\hline & Difference & $0.52 * * *$ & \\
\hline
\end{tabular}

Source: own study.

In Table 7 one can note, in general, bigger differences in values of the Competitiveness Index than in the previous table. It means that the type of service is, to some extent, a better criterion for analyzing the processes in question than the level of employment. The results indicate that the intensity of KM and MO processes is not equally important for the competitiveness of service companies offering different kinds of services. Despite the fact that in all cases companies with high intensity of KM and MO activities are more competitive, the differences in the Competitiveness Index are not always statistically significant. The biggest and statistically significant difference can be observed in the case of companies offering real estate, information and communication, scientific, technical and other professional services as well as other services. With regard to transport, hotel and restaurant services there is also a relatively big, but statistically not significant, difference. The lowest difference can be observed for companies offering financial and insurance services. One of the reasons for the low level or absence of statistical significances in some of the cases is a small number of companies specializing in particular kinds of services in the sample.

\section{CONCLUSIONS}

The results of analyses presented in the article show that service companies are, on average, characterized by a relatively high level of intensity of knowledge management (KM) 
as well as market orientation (MO) processes. Nevertheless, there are differences when particular kinds of service companies are analyzed, especially those offering different types of services. Another interesting finding is that there are considerable, and in many cases statistically significant, differences in the competitiveness level between those service industry companies that are characterized by highly intensive processes of both kinds (knowledge management and market orientation) and other service-providing companies that exhibit low levels of the intensity of one or both types of these processes. Such results indicate that both elements (KM and MO) constitute important factors for developing competitive advantage of service enterprises. Nevertheless, it can be seen that their importance differs depending on the type of service offered by the company. The processes in question are most important for companies offering real estate, information and communication technology, scientific, technical and other professional services as well as other services.

The conclusions formulated in this article can be used as a practical recommendation for service industry companies. Such businesses should develop the intensity of both kinds of processes - knowledge management and market orientation. The implementation of intensive activities in both areas brings the best results in terms of competitiveness of an enterprise. Nevertheless, increasing the intensity of operations even in one field - knowledge management or market orientation - may also improve the competitiveness of a service company. Particularly companies offering services listed at the end of the previous paragraph should pay attention to this recommendation.

The main contribution of this article lies in showing the importance of simultaneous, $\mathrm{KM}$ and MO activities in one type of enterprises - service industry entities. Other studies have also demonstrated the significance of these two factors. These include studies conducted by Darroch and McNaughton ${ }^{45}$ in New Zealand, Wang et al. ${ }^{46}$ in the United Kingdom and Soniewicki ${ }^{47}$ in Poland. The only study that did not confirm the influence of the factors in question on the competitiveness of companies it analyzed was conducted by Mazur, Rószkiewicz and Strzyżewska ${ }^{48}$ in Poland.

It is difficult to precisely compare the results of this study to those conducted by other authors, as they did not use exactly the same research tools and, in some cases, there were differences in theoretical concepts, but the general idea of those studies was similar. The aforementioned authors examined different kinds of enterprises and conducted studies in different places. For example, Mazur, Rószkiewicz and Strzyżewska ${ }^{49}$ concentrated on medium sized companies, Soniewicki ${ }^{50}$ on firms in the process of internationalization. The last and possibly crucial factor influencing the results is the period in which a survey is conducted. This is probably why Mazur, Rószkiewicz and Strzyżewska ${ }^{51}$ did not confirm the

45 J. Darroch, R. McNaughton, Beyond Market Orientation. Knowledge Management and the Innovativeness of New Zealand Firms, "European Journal of Marketing" 37, 3/4 (2003), pp. 572-593.

${ }^{46}$ C.L. Wang, G.T.M. Hult, D.J. Ketchen, P.K. Ahmed, Knowledge management orientation, market orientation, and firm performance: an integration and empirical examination, "Journal of Strategic Marketing" Vol. 17, No. 2 (2009), pp. 99-122.

47 M. Soniewicki, The company's...

48 J. Mazur, M. Rószkiewicz, M. Strzyżewska, Orientacja na wiedzę a wyniki przedsiębiorstwa. Wyniki badań średnich przedsiębiorstw funkcjonujących w Polsce, Szkoła Główna Handlowa w Warszawie, Warszawa 2008.

49 Ibidem.

${ }^{50}$ M. Soniewicki, The company's...

51 J. Mazur, M. Rószkiewicz, M. Strzyżewska, Orientacja na wiedze... 
influence of the factors of interest on the competitiveness in their study. Economic conditions in Poland are changing. The Polish economy is becoming more knowledge based and the difference in the results may be the effect of the increasing role of knowledge in creating competitive advantage by companies in Poland.

\section{LIMITATIONS OF THE STUDY AND RECOMMENDATIONS FOR FU- TURE RESEARCH}

The research method used in this study imposes certain limitations. The first one is associated with the fact that the study involved quantitative methods. As such, it could not measure processes which take place in those enterprises in detail. This limitation is especially evident in the area of knowledge management. Additionally, the survey questionnaire used was relatively simple and short in order to ensure the highest possible response rate and good quality. Moreover, quantitative research does not take into account the quality of processes occurring in companies, and, according to Martine $\mathrm{z}^{52}$, bad quality is a huge threat, especially for KM processes. Another limitation is the fact that the data obtained are the result of self-assessment by company employees, which, in some cases, may decrease its quality.

Research on the role of knowledge management and market orientation in the competitiveness of service enterprises should be continued, given the importance of these factors that this article has tried to demonstrate. Such research could concentrate on particular types of service companies in order to understand what sort of knowledge management and market orientation processes are most effective in their case and fit their business characteristics. Such knowledge could be obtained by means of qualitative research, which is better suited to account for the diversity of service industry companies.

\section{REFERENCES}

[1] Ahmed P.K., Lim K.K., Loh A.Y.E., Learning Through Knowledge Management, Butterworth-Heinemann, Oxford 2002.

[2] Bali R.K., Wickramasinghe N., Lahaney B., Knowledge Management Primer, Routledge, London 2009.

[3] Brdulak J.J., Zarzadzanie wiedza a proces innowacji produktu, Szkoła Główna Handlowa Oficyna Wydawnicza, Warszawa 2005.

[4] Brinkley I., Defining the knowledge economy, The Work Foundation, London 2006.

[5] Bukh P.N., Christensen K.S., Mouritsen J., Knowledge Management and Intellectual Capital - Establishing a Field of Practice, Palgrave Macmillan, New York 2005.

[6] Darroch J., McNaughton R., Beyond Market Orientation. Knowledge Management and the Innovativeness of New Zealand Firms, "European Journal of Marketing" 37, $3 / 4$ (2003), pp. 572-593.

[7] Evans Ch., Zarzadzanie Wiedza, Polskie Wydawnictwo Ekonomiczne, Warszawa 2005.

[8] Fonfara K., Zachowanie przedsiębiorstwa $w$ procesie internacjonalizacji - podejście sieciowe, Polskie Wydawnictwo Ekonomiczne, Warszawa 2009.

\footnotetext{
52 A.R.M. Martinez, Micro-Bargaining as Enhancer of Knowledge Management. A Comparison Between Mexico and Germany, Rainer Hamp Verlag, München and Mering 2010, p. 29.
} 
[9] Fonfara K., The Development of Business Networks in the Company Internationalisation Process, Poznań University of Economics Press, Poznań 2012.

[10] Gaczek W.M., Gospodarka oparta na wiedzy w regionach europejskich, Komitet Przestrzennego Zagospodarowania Kraju PAN, Warszawa 2009.

[11] Grönfeldt S., Stroher J., Service Leadership. The Quest for Competitive Advantage, SAGE Publications, London 2006.

[12] GUS, PKD 2007, 2007, http://www.stat.gov.pl/klasyfikacje/pkd_07/pdf/2_PKD-2007schemat_2.pdf (26.03.2012 r.).

[13] Handzic M., Zhou A.Z., Knowledge Management. An Integrative Approach, Chandos Publishing, Oxford 2005.

[14] Hooley G., Cox T., Fahy J., Shipley D., Beracs J., Fonfara K., Snoj B., Market Orientation in the Transition Economies of Central Europe, "Journal of Business Research" 50 (2000), pp. 273-285.

[15] Jashapara A., Zarzqdzanie wiedzq, Polskie Wydawnictwo Ekonomiczne, Warszawa 2006.

[16] Kahin B., Foray D., Advancing Knowledge and the Knowledge Economy, Massachusetts Institute of Technology, Cambridge 2006.

[17] Karlsson Ch., Johansson B., Sough R.R., Entrepreneurship and Dynamics in the Knowledge Economy, Routledge, New York 2006.

[18] Kaur G., Sharma R.D., Seli N., A Balanced Approach towards Market Orientation, "Vikalpa", Vol. 38, No. 3, July-September (2013), pp. 51-65.

[19] Kłak M., Zarzadzanie wiedzq we współczesnym przedsiębiorstwie, Wydawnictwo Wyższej Szkoły Ekonomii i Prawa im. prof. Edwarda Lipińskiego w Kielcach 2010.

[20] Kohli A.K., Jaworski B.J., Market Orientation: The Construct, Research Propositions, and Managerial Implications, "Journal of Marketing" April (1990), pp. 1-18.

[21] Kohli A.K., Jaworski B.J., Kumar A., MARKOR: A Measure of Market Orientation, "Journal of Marketing Research" Vol. 30, November (1993), pp. 467-477.

[22] Liebowitz J., Making Cents Out of Knowledge Management, The Scarecrow Press, inc., Laham 2008.

[23] Martinez A.R.M., Micro-Bargaining as Enhancer of Knowledge Management. A Comparison Between Mexico and Germany, Rainer Hamp Verlag, München and Mering 2010.

[24] Mazur J., Rószkiewicz M., Strzyżewska M., Orientacja na wiedzę a wyniki przedsiębiorstwa. Wyniki badań średnich przedsiębiorstw funkcjonujacych w Polsce, Szkoła Główna Handlowa w Warszawie 2008.

[25] Moszkowicz M., Kubiński P., Edukacja akademicka a tworzenie w Polsce gospodarki opartej na wiedzy [in:] Wiedza w gospodarce i gospodarka oparta na wiedzy. Edukacja w gospodarce opartej na wiedzy, red. M. Hopej, M. Moszkowicz, J. Skalik, Wydawnictwo Uniwersytetu Ekonomicznego we Wrocławiu, Wrocław 2010.

[26] Narver J.C., Slater S.F., The Effect of a Market Orientation on Business Profitability, "Journal of Marketing" Vol. 54, No. 4, October, (1990), pp. 20-35.

[27] Nijkamp P., Siedschlag I., Innovation, Growth and Competitiveness. Dynamic Regions in the Knowledge-Based World Economy, Springer, Berlin 2011.

[28] OECD, The Knowledge-Based Economy, Paris 1996.

[29] Paliszkiewicz J.O., Zarzadzanie wiedza w matych i średnich przedsiębiorstwach - koncepcja oceny i modele, Wydawnictwo SGGW, Warszawa 2007. 
[30] Pelham A.M., Wilson D.T., A Longitudinal Study of the Impact of Market Structure, Firm Structure, Strategy, and Market Orientation Culture on Dimensions of Small-Firm Performance, "Journal of the Academy of Marketing Science" Vol. 24, No. 1 (1996), pp. 27-43.

[31] Ratajczak-Mrozek M., Sieci biznesowe a przewaga konkurencyjna przedsiębiorstw zaawansowanych technologii na rynkach zagranicznych, Wydawnictwo Uniwersytetu Ekonomicznego w Poznaniu 2010.

[32] Shapiro B.P., What the Hell is 'Market Oriented'?, "Harvard Business Review" Vol. 66 (1988), pp. 119-125.

[33] Soniewicki M., Wykorzystanie kooperacyjnych źródet wiedzy w przedsiębiorstwach ustugowych, "Studia Oeconomica Posnaniensia" No. 1 (2014a), pp. 46-60.

[34] Soniewicki M., The characteristics of knowledge management processes in the Polish service industry companies, "Przegląd Organizacji" No. 7 (2014b), pp. 40-46.

[35] Soniewicki M., The company's international competitive advantage - the role of knowledge, Difin, Warsaw 2015.

[36] Stankiewicz M.J., Zarządzanie Wiedza Jako Kluczowy Czynnik Międzynarodowej Konkurencyjności Przedsiębiorstwa, Wydawnictwo “Dom Organizatora”, Toruń 2006.

[37] Szyjewski Z., Nowak J.S., Grabara J.K., Strategie Informatyzacji i Zarzqdzania Wiedza, Wydawnictwa Naukowo-Techniczne, Warszawa 2004.

[38] Wang C.L., Hult G.T.M., Ketchen D.J., Ahmed P.K., Knowledge management orientation, market orientation, and firm performance: an integration and empirical examination, "Journal of Strategic Marketing" Vol. 17, No. 2 (2009), pp. 99-122.

[39] Welfe W., Gospodarka oparta na wiedzy, Polskie Wydawnictwo Ekonomiczne, Warszawa 2007.

[40] Weresa M.A., Establishing Competitive Advantages in the Service Sector in EU Member States, Peter Lang, Frankfurt am Main 2010.

[41] Woodall J., Lee M., Stewart J., The knowledge revolution and the knowledge economy: the challenge for HRD. New Frontiers in HRD, Routledge, London 2004.

\section{ZARZADZANIE WIEDZA, ORIENTACJA RYNKOWA I KONKURENCYJNOŚĆ PRZEDSIĘBIORSTW FUNKCJONUJĄCYCH W BRANŻY USŁUGOWEJ}

Celem niniejszego artykułu jest analiza roli procesów w obszarze zarządzania wiedzą i orientacji rynkowej $\mathrm{w}$ tworzeniu przewagi konkurencyjnych przedsiębiorstw funkcjonujących w branży usługowej. Publikacja jest oparta na wynikach badania ilościowego, w którym przebadano 381 przedsiębiorstw ze wspomnianej branży. Poziom orientacji rynkowej analizowanych przedsiębiorstw był mierzony z wykorzystaniem skali MKTOR stworzonej przez Narvera i Slatera ${ }^{53}$. Intensywność procesów w zakresie zarządzania wiedzą była sprawdzana za pomocą Indeksu ZW (KM Index) stworzonego na podstawie licznych źródeł literaturowych. Kluczowym wnioskiem z przeprowadzonych analiz jest, że przewaga konkurencja przedsiębiorstw usługowych jest silnie powiązana z intensywnością ich procesów w zakresie zarządzania wiedzą i orientacji rynkowej. Ponadto bardziej szczegółowe analizy pokazują, że znaczenie tych czynników różni się w zależności od rodzaju usług oferowanych przez badane przedsiębiorstwa. Intensywne działania w obu badanych obszarach - zarządzania wiedzą

53 J.C. Narver, S.F. Slater, The Effect of a Market Orientation on Business Profitability, "Journal of Marketing" vol. 54, no. 4, October, (1990), pp. 20-35. 
i orientacji rynkowej - przynoszą najlepsze rezultaty w zakresie konkurencyjności przedsiębiorstwa. Niemniej jednak, wzrost intensywności działań nawet $\mathrm{w}$ jednym $\mathrm{z}$ wymienionych obszarów może również zwiększyć poziom konkurencyjności przedsiębiorstwa usługowego. Artykuł przedstawia unikalny wgląd w procesy zarządzania wiedzą i orientacji rynkowej w różnorodnych rodzajach przedsiębiorstw działających w branży usługowej, a także pokazuje związek pomiędzy wspomnianymi czynnikami a konkurencyjnością analizowanych firm.

Słowa kluczowe: zarządzanie wiedzą, orientacja rynkowa, branża usługowa, przewaga konkurencyjna, konkurencyjność.

DOI: 10.7862/rz.2017.mmr.21

Tekst złożono w redakcji: luty $2017 \mathrm{r}$.

Przyjęto do druku: czerwiec 2017 r. 